\title{
Traffic-related Noise at Roadside Schools: Assessment and Prediction in Urban Setting
}

\section{Tingkat Kebisingan Lalu Lintas di Sekolah Tepi Jalan: Penilaian dan Prediksi di Lingkungan Perkotaan}

\author{
MILA DIRGAWATI ${ }^{*}$, GITA NUR APRIANI ${ }^{1}$, ASTIEN ARTSEN ASYARI ${ }^{1}$ DAN R. TRIYOGO \\ ${ }^{1}$ Environmental Engineering Study Program, Faculty of Civil and Planning, Institut Teknologi Nasional Bandung, Indonesia \\ ${ }^{2}$ Faculty of Industrial Technology, Institut Teknologi Bandung, Indonesia \\ Email: mila.dirgawati@itenas.ac.id
}

\begin{abstract}
ABSTRAK
Kebisingan lalu lintas adalah salah satu ancaman bagi kesehatan masyarakat perkotaan. Paparan bising memberikan efek kesehatan jangka pendek dan panjang, dan efeknya berpotensi lebih buruk pada anakanak yang belajar di sekolah pinggir jalan. Penelitian ini bertujuan untuk mengkarakterisasi kebisingan lalu lintas jalan di sekolah-sekolah yang terletak di jalan-jalan utama di Bandung, Indonesia serta memberikan rekomendasi mitigasi dan adaptasi untuk pengendalian kebisingan. Kebisingan lalu lintas diperoleh di dua sekolah pinggir jalan terletak di dua jalan utama (Jalan Suci dan Djuanda), beserta data volume dan komposisi lalu lintas, serta kecepatan kendaraan. Pengukuran dilakukan antara jam sekolah selama satu hari yang mewakili lokasi trotoar jalan, depan sekolah, dan halaman sekolah. Parameter tingkat kebisingan yang penting (Leq, L10, L50, L90) diukur, dan dilakukan analisis korelasi antara masing-masing parameter kebisingan. Model CoRTN digunakan untuk memprediksi kebisingan lalu lintas pada jarak tertentu dari jalan raya. Sepeda motor merupakan jenis kendaraan dominan secara berturut $79,1 \%$ dan $67,1 \%$ dari total volume kendaraan di ruas jalan Suci dan Djuanda. Kendaraan berat menyumbang $<1 \%$. Mayoritas kebisingan lalu lintas yang diukur sebagai Leq, L10, L50, L90 melebihi batas maksimum untuk pinggir jalan dan zona sekolah menurut standar internasional dan nasional $<55$ dBA). Model tersebut berkinerja lebih baik di ruas jalan Djuanda daripada Suci. Jumlah lokasi dan waktu pengukuran yang lebih banyak dapat memberikan penilaian paparan tingkat kebisingan lalu lintas yang lebih baik dengan menggunakan model CoRTN. Hasil penelitian ini diharapkan dapat menjadi masukan kebijakan berbasis pengetahuan bagi pemerintah kota dan lembaga untuk mengurangi dampak bising bagi anak didik.
\end{abstract}

Kata kunci: kebisingan lalu lintas jalan, tingkat kebisingan, Model CoRTN

\begin{abstract}
Road traffic noise is one of the most ubiquitous threats to public health in an urban setting. Its exposures have proven short-and long-term health effects and potentially worse for children studying at roadside schools. This study aimed to characterize the traffic noise at schools located on primary roads in Bandung, Indonesia, and propose recommendations for future mitigations and adaptation measures. Traffic noise was obtained from two roadside schools at two primary roads (Suci and Djuanda roads) and data on traffic volume, traffic composition, and vehicle speed. The measurement was conducted between school hours during one daytime only at locations representing roadside, front of the school, and schoolyard. We recorded important noise level parameters (Leq, L10, L50, L90) and analyzed the correlation between each parameter. The Calculation of Road Traffic Noise (CoRTN) model was applied to predict the traffic noise at specific distances from the road. The predominant vehicle was motorcycles, which accounted for $79.1 \%$ and $67.1 \%$ of the total vehicle volume on Suci on Djuanda segments, respectively. Heavy vehicles accounted for $<1 \%$. The majority of measured Leq, L10, L50, L90 exceeded the maximum limit for roadside and school zone set by the international and national standards $(<55 \mathrm{dBA})$. The CoRTN model performed better in Djuanda than in Suci segment. More measurement locations and times could better assess exposure to traffic noise levels at roadside schools using the CoRTN model. The results of this study are expected to be a recommendation for developing knowledge-based policies and measures to reduce the impact of traffic noise on students
\end{abstract}

Keywords: road traffic noise, noise level, CoRTN mode 


\section{INTRODUCTION}

\subsection{Research Background}

Environmental noise pollution in urban areas is one of the most important environmental threats to the public health worldwide ${ }^{(1,2)}$, with the road traffic being a major cause ${ }^{(3)}$. According to the World Health Organization (WHO), at least 100 million inhabitants were exposed to road traffic noise levels beyond the maximum limit in urban areas in Europe, and over 1.6 million healthy years of life are lost due to exposure to road traffic noise in Western Europe region ${ }^{(3)}$.

Exposures to road traffic noise pollution at excessive levels have proven short-and long-term effects on health. These include sleep disruption, hypertension, heart disease, and hearing loss ${ }^{(4,5)}$. There is also evidence of some noise exposures may be worse for particular vulnerable population groups such as school children ${ }^{(6)}$ because of their lack of ability to control environmental stressors ${ }^{(4)}$. It was reported that school children in urban areas and exposed to long term excessive ambient noise levels have shown stress symptoms, and decrease the cognitive ability such as reduced learning ability, reading skills, language development, memory, motivation and concentration $^{(7)}$. Moreover, children attending schools located in busy roadways are more likely to have reduced learning concentrations and lower academic tests ${ }^{(8-10)}$. Road traffic noise levels have shown gradients with distance from roads ${ }^{(11)}$, suggesting children studying at near roads could have the highest exposures. Van Kamp et al. (2013) found that these effects on school children were observed at traffic noise levels above $50 \mathrm{dBA}^{(6)}$. A reliable estimation of the exposure to ambient noise at roadside schools is therefore important for health risk assessment purposes.

Earlier studies investigating traffic noise pollution in urban areas have used various methods for noise predictions, including traffic noise models. The Calculation of Road Traffic Noise (CoRTN) approach is among the available models applied to predict the level of noise originating from road traffic sources ${ }^{(12)}$ in areas with a low and high proportions of motorcycles ${ }^{(13)}$. Both measurements and predictions of road traffic noise levels at particular locations are essential for roadway planning and for designing the noise abatement plan.

Bandung is the third most populous city in Indonesia and one of the fastest-growing cities in West Java Province, Indonesia. The city experiences rapid population growth, urbanization, infrastructure development, as well as road network and transportation expansion which potentially results in a subsequent increase in traffic-related noise. Many schools in Bandung are located in the adjacent of major roads or heavily travelled roadways. A previous study had reported the measured noise levels in a school in Bandung was $66.06 \mathrm{dBA}$ which above the maximum limit according to the national standard for a school environment ${ }^{(14)}$. However, there are limited assessments of exposure to traffic-related noise at roadside schools in Bandung. These efforts are important to mitigate traffic-related noise and prevent the adverse impacts on school children.

\subsection{Aims of Study}

This study aims are: (1) to assess the ambient level of traffic noise at selected primary roadside schools in Bandung City Indonesia; (2) using real-time measured noise level as well as the CoRTN model predicted noise levels; and (3) propose future mitigation and adaptation measures to reduce the impact of exposure to traffic-related noise at roadside schools.

\section{MATERIALS AND METHODS}

\subsection{Area of Study}

This study was conducted in Bandung City, the capital of West Java Province, Indonesia. The city is one of the largest metropolitan cities in Indonesia, with about 2.5 million inhabitants in $2019^{(15)}$. The rate of vehicle growth was $11 \%$ annually, substantially exceeded Bandung's population growth rate $(0.47 \%)^{(15)}$. The vehicle fleet consists of private cars, motorcycles, heavy vehicles (buses and trucks). The number of registered vehicles in 2019 was 1,251,080 units of two-wheeled vehicles and 536,973 units of four wheels vehicles $^{(15)}$.

\subsection{Data Collection}

\subsubsection{Site selection}

The traffic-related noise in urban setting is presented by two arterial or primary roads with high traffic volume: Jalan Surapati - Cicaheum (Suci road) and Jalan Ir H Djuanda (Djuanda road). The primary road was categorized based on the Decree of the Minister of Public Works and Public Housing Number 245 of $2015^{(16)}$. One roadside school located at Suci and Djuanda roads was chosen as case studies. The length of the roadside school was determined as the road segment length, with characteristics were being adequate for the application for CoRTN model: straight segment with asphalt mixture surface course, had two lanes for each direction and flat gradients. The location of selected road segments as shown in Figure 1. 


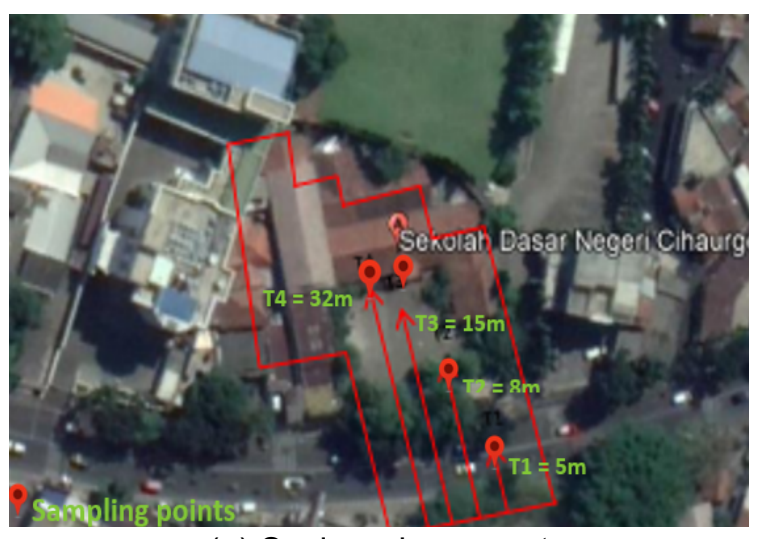

(a) Suci road segment

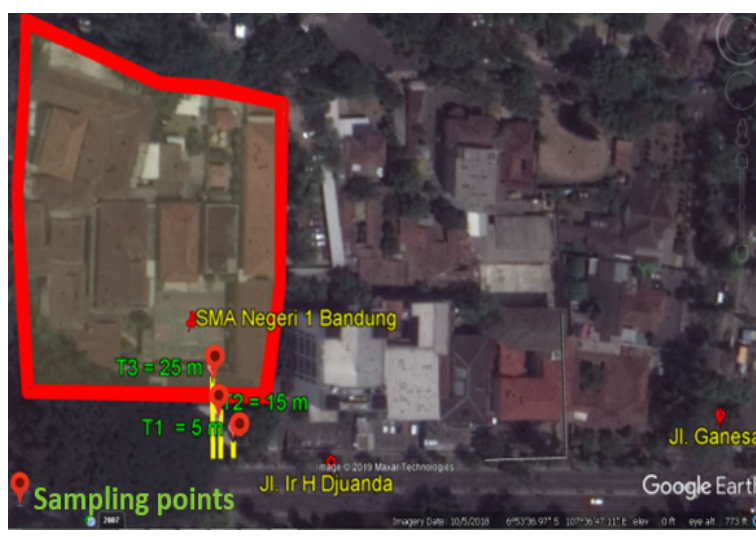

(b) Djuanda road segment

Figure 1. Location of selected road segments and sampling locations in Bandung, Indonesia

\subsubsection{Measurement of Traffic Noise level}

The traffic noise level was measured using a Sound Level Meter (SLM Luthron 2310L), with procedures based on the method measuring the ambient noise level (SNI 8427:2017) and Decree of the Minister of Environment Number 48 of 1996 on Noise Level Standard. The sound level meter was placed at $1.20-1.50 \mathrm{~m}$ height from the ground surface to avoid the reflections from the ground, and the microphone of the instrument was set perpendicular to the axis of the road lane. The noise measurement points were located in the middle of the road segments to better capture the influences of road characteristics on traffic noise.

The duration of each measurement at each sampling location was 10 minutes with data record every 5 seconds to determine 10-minute equivalent continuous sound pressure levels (L10) in dBA. For maintaining accuracy, the sound level meters were calibrated at the beginning and end of each measurement day. We also documented weather condition such as rain/dry, ambient temperatures, and wind as well as other noise sources. The levels of noise

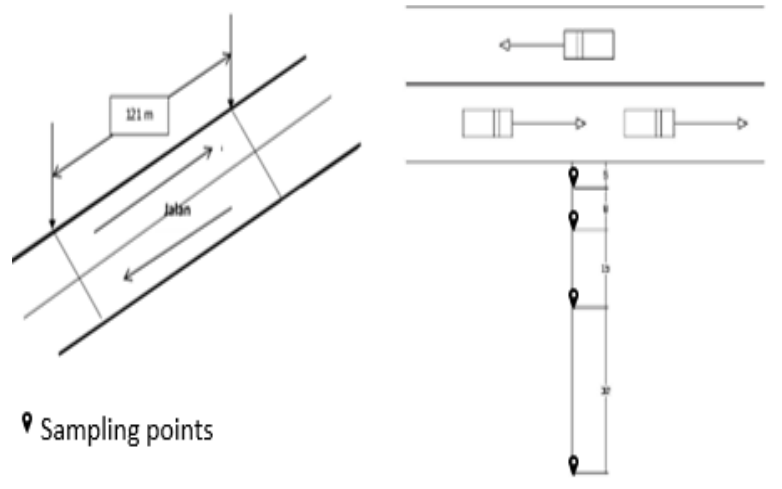

(a) Suci road segment parameters were measured only between the school hours during one day-time of weekdays to capture the highest noise levels and the time when most noise exposures occur during school hours. The traffic noise was measured in different measurement periods during the school hours at particular distances from the road. The measurement in Suci road segment was conducted from 23 September 2019 in the early morning (07.00), morning (09.00), and noon (12.00), at following distances from the road: $5 \mathrm{~m}$ (point-1), $8 \mathrm{~m}$ (point-2), $15 \mathrm{~m}$ (point-3), and $32 \mathrm{~m}$ (point-4). Meanwhile, for Djuanda road segment, the measurement was conducted between 20-21 May 2019 in the early morning (07.00), morning (09.00), afternoon (15.00) and evening (17.00) at distances of $5 \mathrm{~m}$ (point-1), $15 \mathrm{~m}$ (point-2), and 25 $m$ (point-3) from the road. The selected point-1 represented the noise levels a at roadside, point2 represented the school front, and point- 3 and point-4 represented the schoolyard environment. Figure 2 illustrates the typical cross-section of both road segments and measurement locations.
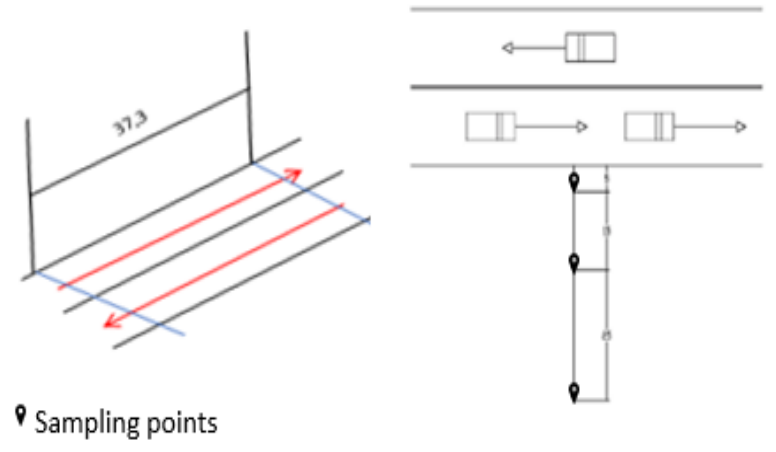

(b) Djuanda road segment

Figure 2. Typical cross section of selected road segments and sampling locations. 


\subsubsection{Measurement of Traffic Characteristics}

The measured traffic characteristics, which included volume and composition of traffic, and average vehicles speed along each road segment were measured simultaneously with the noise levels measurements. A 15-minute total number of vehicles along each segment were recorded for two vehicle categories: heavy vehicles or vehicles with an unladen weight exceeding 1,525 $\mathrm{kg}$, light vehicles with a maximum unladen weight of $1,525 \mathrm{~kg}$, and two-wheeler vehicles or motorcycles. The heavy-duty vehicles included buses and trucks, while light vehicles included four-wheeler passenger vehicles such as private cars, taxies and small vans. The composition of heavy vehicles (\%) was then determined for the CoRTN modeling purposes. The traffic volume and composition were measured following the Guidelines for Manual Traffic Numeration Survey (Pd.T-19 2004-B) $)^{(17)}$. The average of individual speeds was calculated based upon the time interval that selected vehicles took to go through the road segment, as described in the Guideline for Survey and Traffic Travel Time Calculation No.001/T/BMKT/1990. It was assumed that the speed of each vehicle remained unchanged along the road segment and was calculated as follows:

$$
\mathbf{V}=\frac{3,6 \mathrm{~J}}{\mathrm{~W}}
$$

Where

$V=$ vehicle's speed $(\mathrm{km} /$ hour); $J=$ length of road segment $(\mathrm{m}) ; \mathrm{W}=$ time (second).

\subsubsection{Perception of Individuals on Traffic Noise} and Its Effects

Perceived exposure to traffic noise, as well as perception and knowledge of traffic noise and its effects, were identified through a questionnaire. A simple random sampling was conducted during the same measurement period of noise and traffic characteristics. The sampling subjects were teacher, students, and nonacademic staffs of the schools, and the number of selected subjects were determined based on Slovin formula as follows:

$$
\begin{aligned}
& n= \\
& \frac{N}{\left(1+N e^{2}\right)} .
\end{aligned}
$$

Where $\mathrm{n}$ is the size of samples, $\mathrm{N}$ is the size of the population (96 teachers, 96 non-academic staff, and 1,144 students), and $\mathrm{e}$ is the error margin (10\%). In total, 94 subjects were selected, included 8 teachers, 8 non-academic staff, and 80 students. The results from the questionnaires, the measured and the CoRTN predicted noise levels were then considered for developing recommendation for future mitigation of traffic noise.

\subsection{Data Analysis}

\subsubsection{Traffic noise level}

The traffic noise levels at each receiver point were expressed as continuous equivalent Aweighted sound level (LAeq) to represent noise intensity as perceived by the human ear. The statistical percentage sound level such as L10, L50, and L90 was also used to represent the noise level that was exceeded during $10 \%, 50 \%$, and $90 \%$ of the measurement period, respectively. The predicted noise level was expressed as L10, 1 hour.

\subsubsection{Prediction of noise level by CoRTN model}

The CoRTN model predicts an hourly basic noise level at particular locations for a given one hour reference time at an average vehicle speed of $75 \mathrm{~km} /$ hour, with heavy vehicles composition of $0 \%$, and the road gradient was $0 \%{ }^{(18,19)}$. The predicted basic noise level was then adjusted to consider the composition and speed of the vehicles, the nature of road surface, nonzero road gradient, and the effects of distance from the source line ${ }^{(19)}$.

The basic hourly noise level was expressed in $\mathrm{dBA}$ and was calculated using the following equation:

$$
\begin{array}{r}
L_{\text {Basic }}=42.2+ \\
10 \log 10 q \ldots \ldots \ldots \ldots \ldots \ldots
\end{array}
$$

where $L_{\text {Basic }}$ was the basic hourly noise level; $q$ was the hourly total traffic volume that included all heavy and light vehicles as well as motorcycles. The adjustment of a measured average of traffic speed and proportion of heavy vehicles were as follow:

$$
\begin{aligned}
& \mathrm{C}_{\text {speed }}=33 \log 10\left(\mathrm{~V}+40+\frac{500}{\mathrm{~V}}\right)+10 \log 10 \\
& \left(1+\frac{5 \mathrm{p}}{\mathrm{V}}\right)-68.8 \mathrm{dBA} \ldots \ldots \ldots \ldots \ldots \ldots \ldots \ldots \ldots \ldots \ldots \ldots \ldots \ldots \ldots \ldots \ldots
\end{aligned}
$$

where $C_{\text {speed }}$ was speed correction; $V$ was hourly average speed; and $P$ was the proportion of heavy vehicles on each road segment given by:

$$
p=\frac{100 \mathrm{f}}{\mathrm{q}}
$$

where $f$ was determined as the heavy vehicles flow per hour. For a nonzero road gradient, the adjustment for road gradient or G (\%) was calculated by:

$$
\mathrm{C}_{\text {gradient }}=0.3 \mathrm{G} \mathrm{dBA} \text {. }
$$


The basic noise level was also adjusted for the effects of distance from the source, the characteristics of the ground surface, and reflections from surrounding buildings. The distance correction was determined by this equation:

$$
\begin{aligned}
& C_{\text {distance }}=-10 \log 10\left(\frac{\mathrm{d} \prime}{13.5}\right) \\
& \mathrm{dBA} \ldots \ldots \ldots \ldots(7)
\end{aligned}
$$

where $d$ ' was the distance of the shortest slant between the traffic and the receiver/measurement point, while $d$ was the shortest horizontal distance from the traffic, which was assumed at least of 4 m-length. d' was calculated as $\left((d+3.5)^{2}+h^{2}\right.$ )$^{0,5}$, where $h$ was the vertical distance between the source and the receiver. The correction for the ground cover was calculated as the function of the shortest horizontal distance (d), the average height $(\mathrm{H})$, and the absorbing ground proportion (I) from the traffic source to the reception point (Table 1 ).

Table 1. Correction of ground reflection

\begin{tabular}{cc}
\hline Road characteristics & Correction \\
\hline $0.75<\mathrm{H}<(\mathrm{d}+5) / 6$ & $5.2 I \log 10(6 H-1.5 /(d+$ \\
& $3.5))$ \\
$\mathrm{H}<0.75$ & $5.2 I \log 10(3 /(d+3.5))$ \\
$\mathrm{H} \geq(\mathrm{d}+5) / 6$ & 0 \\
\hline
\end{tabular}

Subsequently, the correction of ground reflection was added to the basic noise level:

$$
C_{\text {reflection }}=1.5\left(\frac{\theta^{\prime}}{\theta}\right) \mathrm{dBA} \text {. }
$$

where $\theta^{\prime}$ was the the road angle view (in degrees), and $\theta$ was the sum of reflecting angles from the opposite facades/buildings to the receptor.

Finally, the predicted noise level determined as L10 predicted as follows:

$$
\begin{aligned}
& \mathrm{L} 10 \text { predicted }=\mathrm{L}_{\text {basic }}+\mathrm{C}_{\text {speed }}+\mathrm{C}_{\text {gradient }}+ \\
& \mathrm{C}_{\text {reflection }} \ldots \ldots \ldots \ldots \ldots \ldots \ldots \ldots \ldots \ldots \ldots \ldots \ldots \ldots \ldots \ldots \ldots \ldots \ldots \ldots \ldots \ldots \ldots \ldots \ldots \ldots
\end{aligned}
$$

The predicted noise levels were then compared with the corresponding measured noise level to evaluate the CoRTN model application. The differences between the predicted and the measured noise level should not exceed $3 \mathrm{dBA}$ as suggested by the Federal Highway Administration.

\section{RESULTS AND DISCUSSION}

The data collected included real-time traffic noise level, traffic composition, volume, vehicle speed, and characteristics of road segments measured simultaneously. There were no obstacles or disturbances (such as accidents or obstructed traffic) observed during the measurement.

\subsection{Traffic Characteristics}

The observed mean speed of the vehicles,

\begin{tabular}{|c|c|c|c|c|c|c|c|c|}
\hline \multirow{2}{*}{$\begin{array}{l}\text { Measurement } \\
\text { Location/ Time }\end{array}$} & \multicolumn{5}{|c|}{ Traffic volume (vehicles per hour) } & \multicolumn{3}{|c|}{ Vehicle speed (km/hour) } \\
\hline & Total & MC & LV & HV & $\% \mathrm{HV}$ & MC & LV & HV \\
\hline \multicolumn{9}{|l|}{ Suci segment: } \\
\hline Early morning & 8628 & 7230 & 1262 & 136 & 1.6 & 46.3 & 34.2 & 29.8 \\
\hline Morning & 10816 & 8378 & 2335 & 103 & 0.9 & 60.8 & 36.4 & 34.0 \\
\hline Noon & 7578 & 5767 & 1692 & 119 & 1.6 & 64.9 & 36.2 & 32.9 \\
\hline Average & 9007 & 7125 & 1763 & 119 & & 57.3 & 35.6 & 32.2 \\
\hline \multicolumn{9}{|l|}{ Djuanda segment: } \\
\hline Early morning & 7977 & 5795 & 2145 & 37 & 0.5 & 50.7 & 38.6 & 33.4 \\
\hline Morning & 6429 & 4223 & 2135 & 71 & 1.1 & 44.0 & 34.0 & 30.6 \\
\hline Afternoon & 4534 & 3050 & 1459 & 25 & 0.6 & 41.5 & 31.2 & 29.3 \\
\hline Evening & 7539 & 4705 & 2776 & 58 & 0.8 & 38.9 & 30.6 & 28.9 \\
\hline Average & 6620 & 4443 & 2129 & 48 & & 43.8 & 33.6 & 30.6 \\
\hline
\end{tabular}
traffic volume, the ratio of heavy vehicles to the total traffic volume for each vehicle type is presented in Table 2.

Table 2. Measured traffic volumes (vehicles/hour) and mean speed ( $\mathrm{km} /$ hour)

Remark: MC: Motorcycle, LV: Light Vehicles, HV: Heavy vehicles, \%HV: proportion of heavy vehicle to traffic volume.

The results show that the highest hourly traffic volume (vehicles/hour) during each measurement period occurred on Suci road segment. The Suci segment links the populated area to the downtown which comprised the center of commercial activities, and public administration and services. The observed vehicle fleets on both road segments predominantly comprised twowheeler vehicles (motorcycles), corresponding to approximately $79.1 \%$ of the traffic volume on Suci and $67.1 \%$ on Djuanda segments. Traffic congestion in Bandung City has made the 
motorcycle as one of the most preference vehicles to a large number of Bandung inhabitants. The light vehicles accounted for about $32.1 \%$ of traffic volume on Djuanda and $19.6 \%$ on Suci road segments. On the other hand, the proportions of heavy vehicles on both road segments were small, corresponding to less than $1 \%$ of the traffic volume. The observed results were in line with the vehicle number in West Java Province, which increased annually by $12.6 \%$ from 2012 to 2016 , with motorcycles being the dominant vehicle, accounted for $72.2 \%$ in $2019^{(15)}$

The traffic peak hours occurred during the early morning at Suci road segment and morning at Djuanda road segment. Meanwhile, the lowest traffic volume at both road segments occurred during the afternoon. Mornings are typical rush hours in Bandung because most people move to the workplace, school or regular activities for the day during the time course. The observed mean speed of vehicles was $28.9-50.7 \mathrm{~km} / \mathrm{hour}$ on Djuanda segment and 32.9-64.9 km/hour on Suci segment, as shown in Tabel 2. On both selected road segments, the mean speed of motorcycles yields the highest value, while the lowest mean speed was observed for heavy vehicles.

\subsection{Measured Traffic Noise Level}

The measured traffic noise levels at both road segments were determined as percentile noise levels (L90, L50, L10) and Leq (1hour) and presented in Table 3.

Table 3. Measured traffic noise level at suci road segment

\begin{tabular}{|c|c|c|c|c|c|}
\hline Measurement location & Measurement period & L90 & L50 & L10 & Leq (1hour) \\
\hline \multicolumn{6}{|l|}{ Suci road segment: } \\
\hline \multirow[t]{3}{*}{ point -1} & Early morning & 73.0 & 76.4 & 81.5 & 80.5 \\
\hline & Morning & 74.0 & 76.9 & 82.3 & 79.1 \\
\hline & Noon/Afternoon & 70.8 & 84.9 & 88.9 & 86.2 \\
\hline \multirow[t]{3}{*}{ point-2 } & Early morning & 64.8 & 67.2 & 75.4 & 70.9 \\
\hline & Morning & 70.3 & 74.7 & 80.7 & 77.0 \\
\hline & Noon/Afternoon & 64.9 & 69.9 & 76.2 & 71.8 \\
\hline \multirow[t]{3}{*}{ point -3} & Early morning & 65.4 & 73.6 & 80.0 & 75.8 \\
\hline & Morning & 64.5 & 68.6 & 74.6 & 70.7 \\
\hline & Noon/Afternoon & 75.5 & 78.6 & 83.3 & 80.4 \\
\hline \multirow[t]{3}{*}{ point-4 } & Early morning & 68.7 & 74.2 & 84.9 & 76.4 \\
\hline & Morning & 70.2 & 66.3 & 72.4 & 72.6 \\
\hline & Noon/Afternoon & 68.7 & 74.2 & 84.9 & 74.1 \\
\hline \multicolumn{6}{|c|}{ Djuanda road segment: } \\
\hline \multirow[t]{4}{*}{ point -1 } & Early morning & 67.4 & 72.9 & 78.0 & 76.2 \\
\hline & Morning & 72.8 & 74.8 & 67.9 & 76.5 \\
\hline & Afternoon & 69.3 & 70.1 & 67.6 & 78.2 \\
\hline & Evening & 68.2 & 72.6 & 81.8 & 78.0 \\
\hline \multirow[t]{4}{*}{ point-2 } & Early morning & 63.3 & 71.3 & 76.1 & 72.9 \\
\hline & Morning & 70.3 & 73.3 & 74.8 & 73.9 \\
\hline & Afternoon & 65.2 & 69.1 & 74.4 & 71.4 \\
\hline & Evening & 65.8 & 73.1 & 77.3 & 76.0 \\
\hline \multirow[t]{4}{*}{ point -3} & Early morning & 57.0 & 50.2 & 58.6 & 57.2 \\
\hline & Morning & 56.1 & 58.7 & 53.4 & 59.7 \\
\hline & Afternoon & 57.0 & 58.8 & 60.3 & 60.1 \\
\hline & Evening & 54.7 & 58.6 & 60.6 & 61.6 \\
\hline
\end{tabular}

The observed equivalent noise level (Leq) overall measurement locations and time were in the range of 70.1-86.2 dBA in Suci road segment and 57.2-78.2 dBA in Djuanda road segment. Specifically, the roadside equivalent noise levels were 79.1-86.2 dBA in Suci segment, and 76.2$78.2 \mathrm{dBA}$ in Djuanda segment. The measured roadside noise levels are comparable to that in one of the monitoring locations in Kendari City, Indonesia with the roadside noise level of 74-79 $\mathrm{dBA}$ and traffic volume of $3500-4500$ vehicles per hour ${ }^{(20)}$. The results are also within the range of roadside noise levels in other urban areas such as Taiyuan in China ${ }^{(21)}$ and Makurdi Town in Nigeria ${ }^{(22)}$.

Background noise which L90 represented, ranged between 64.8 and $74.0 \mathrm{dBA}$ at Suci segment. Lower level of background noise was observed at Djuanda segment with a range of 54.7-72.8 dBA (Table 3). The background noise level most likely corresponds to a noise level generated by a nearby source, for which road traffic activities on both segments. The L50 noise 
values were recorded 66.3-84.9 dBA for Suci road segment; and 50.2-74.8 dBA for Djuanda segment. At the same time the peaks in the noise (L10) ranged from 72.4-88.9 dBA in Suci segment 60.3-81.8 dBA in Djuanda segment.

The contribution of $\mathrm{L} 90$ and $\mathrm{L} 10$ to the equivalent noise level (Leq) was identified by conducting a correlation analysis between Leq and L90 and L10. The correlation coefficient between the pair of noise parameters is summarized in Table 4. A strong positive correlation between Leq and L50 (>0.9) may indicate the accuracy of the measurements at both road segments since the $L 50$ value represents the mean of the noise level ${ }^{(23)}$. The equivalent continuous noise level in Djuanda segment can be explained by the variation in the background noise levels as indicated by the strong correlation between Leq and L90 (Table 4 ). The results may confirm that the road traffic noise was the predominant source of the background noise level. For Suci segment, however, the correlation coefficients between the Leq and L90; and Leq and L10 may suggest that the noise can be attributed to the background noise levels sensitivity to occasional peaks or short-duration noisy events such as noise from congested traffic ${ }^{(24)}$.

Table 4. Pearson correlation coefficients between noise parameter

\begin{tabular}{lccc}
\hline \multicolumn{1}{c}{ Location } & $\begin{array}{c}\text { Leq and } \\
\text { L90 }\end{array}$ & $\begin{array}{c}\text { Leq and } \\
\text { L50 }\end{array}$ & $\begin{array}{c}\text { Leq and } \\
\text { L10 }\end{array}$ \\
\hline $\begin{array}{l}\text { Suci segment } \\
\begin{array}{l}\text { Djuanda } \\
\text { segment }\end{array}\end{array}$ & 0.53 & 0.94 & 0.67 \\
\hline
\end{tabular}

For both selected road segments at any measurement time, the equivalent noise levels gradually decreased by the distance from the traffic source, as demonstrated in Figure 2. The highest noise level occurred at the roadside, where the distance from the traffic source was at the nearest, whereas the minimum noise level was observed at the farthest distance. The results were consistent with those reported by other road traffic noise studies in urban areas ${ }^{(25)}$. It was suggested that the distance between a road traffic source and a receiver location could affect the noise levels. Each time the distance from the traffic sources doubles, the noise levels at the receiver decreases by three-decibel ${ }^{(26)}$.

The observed noise levels on the primary road near the educational area were above the permissible limit during the day-time of Leq 65 dBA set by the WHO (65 dBA). The observed Leq values were also considered high for noisesensitive areas such as schools' outdoor environment, which exceeded the guideline values for annoyance set at $55 \mathrm{dBA}$ by the WHO (WHO Guidelines for Community noise, 1999).
These observed noise levels reflect the facts that traffic-related noise pollution in Bandung City, particularly at roadside schools was ubiquitous. Long term exposure to noise levels above the permissible limit may negatively affect school children's cognitive ability and skills such as reading, problem solving, attention, and memory ${ }^{(10)}$, as well as on standardized academic test scores ${ }^{(9)}$.

Previous studies had reported that the main factors contributing the traffic noise levels were greater traffic volume and higher vehicles speeds ${ }^{(8,27)}$. The vehicle fleet composition is also an important factor in determining traffic noise levels since motorcycles and heavy vehicles are found to be noisier than light vehicles ${ }^{(28)}$. As seen in Table 2, the equivalent traffic noise level of busier traffic flow, higher vehicles speed, and greater proportion of heavy vehicles was Suci road segment higher than that of the Djuanda segment, which had lower traffic flow, vehicles speed, and proportion of motorcycles and heavy vehicles. The noise level was found higher along the busiest roads ${ }^{(29-31)}$. Specifically, motorcycles have been reported as noisy as heavy vehicles and thus make a significant contribution to the noise level ${ }^{(32)}$. Thus, the proportion of motorcycle in Suci segment which was higher than that of the Djuanda segment might explain the higher traffic noise levels at Suci segment.

The minimum equivalent noise level was observed at the roadside of Suci segment (79.1 dBA) with corresponding heavy vehicles ratio of $0.95 \%$ (Table 2 ). The noise levels reached $\geq 80.5$ $\mathrm{dB}(\mathrm{A})$ when the ratio of heavy vehicles ranged between $1.57-1.58 \%$. The observed results might be suggested that the number of heavy vehicles is possibly an important factor for traffic noise in Suci segment as evident by the smaller proportion of heavy vehicles that have consequently reduced the noise level, in line with those reported by Swain \& Goswami $(2014)^{(24)}$. Heavy vehicles such as trucks produced more noise due to their axle loads and the propulsion system of the exhaust or engines ${ }^{(27,33)}$. In addition, the highest roadside noise levels also occurred when the average speed of motorcycles and light vehicles were at the fastest (64.9 $\mathrm{km} /$ hour for motorcycle and $36 \mathrm{~km} /$ hour for light vehicles). These results consistent with a previous study reporting the most significant contribution of tyre-road interaction for light vehicles and motorcycles to noise types of roads are needed.

\subsection{Predicted Traffic Noise Level by CoRTN model}

This current study used the CoRTN model for traffic noise prediction in Bandung city with high use of motorcycles. The differences of L10 
between the measured and predicted for both Suci and Dago road segments as shown in Figure 3. The range of the differences was -4.37.3 dBA for Suci segment and -4.1-1.3 dBA for Djuanda segment. The largest differences among the six measurements and predictions in Suci road segment were an overestimation of $7.3 \mathrm{dBA}$ at distance of $15 \mathrm{~m}$ from the road in the morning, and an underestimation of $6.3 \mathrm{dBA}$ at distance $15 \mathrm{~m}$ from the road. The CoRTN model overestimated the L10 noise levels at most of the location and time of the measurement on this road segment, although the differences between the measured and predicted L10 were in the range of 2-6 dBA as reported by a previous study applying the CoRTN model in Hong Kong ${ }^{(34)}$. Mak et al. (2016) had reported an overestimation of at least $10 \mathrm{dBA}$ may occur when the CoRTN model was adopted in an area when buildings are located at both sides of the road ${ }^{(35)}$.

For Djuanda road segment, the largest alterations were an overestimation of $4.1 \mathrm{dBA}$ and 4.0dBA which occurred in the early morning at distances of $5 \mathrm{~m}$ and $15 \mathrm{~m}$, respectively. However, the majority of L10 differences values in Djuanda road segment less than the maximum limit of $3 \mathrm{dBA}$ as suggested by the Federal Highway Administration and fairly consistent with the measured noise levels at corresponding measurement points and time as seen in Figure 3.

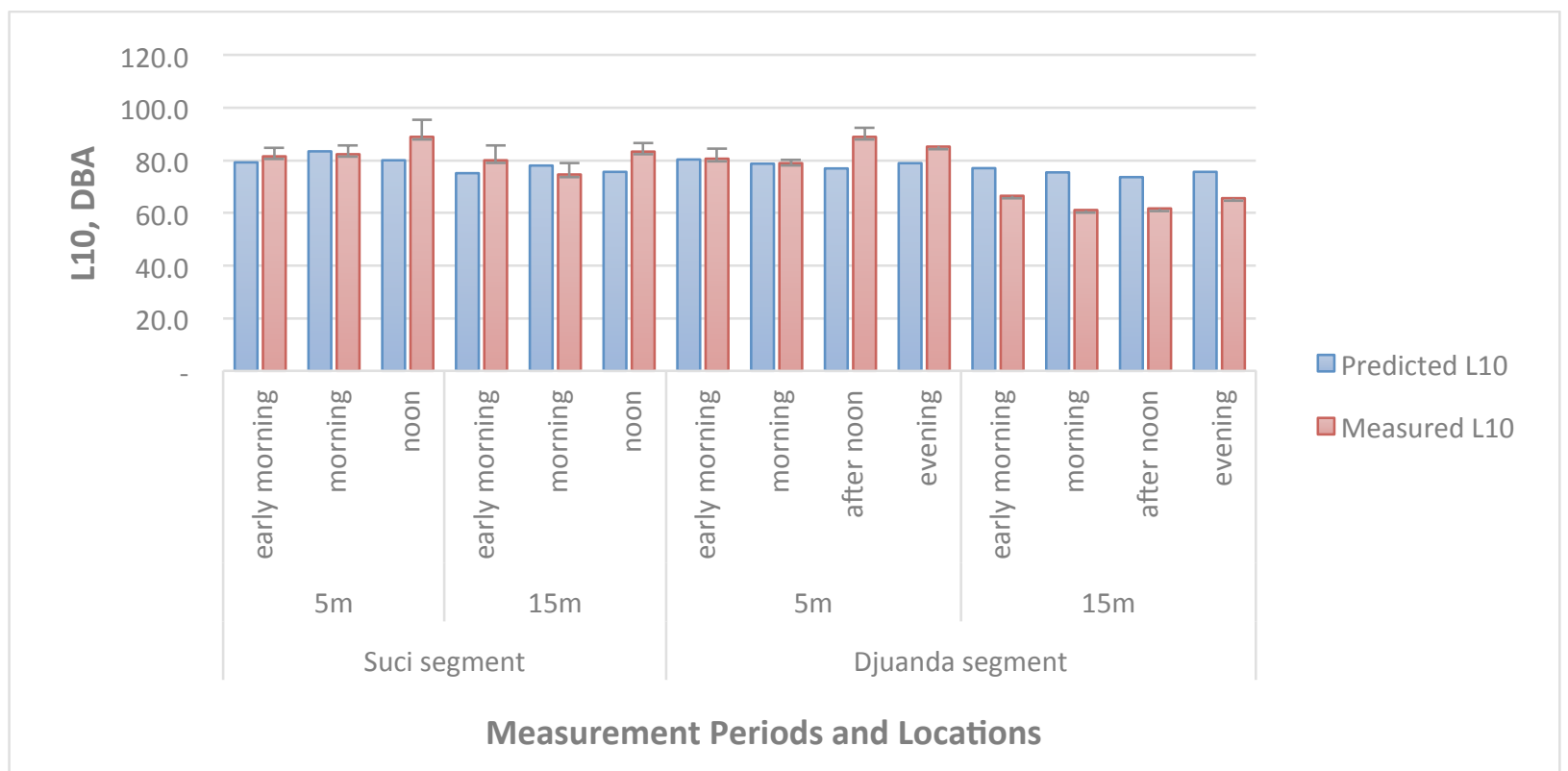

Figure 3. Measured and predicted CORTN noise levels at Suci and Djuanda road segments. Error bars represent standard deviations from the measured values.

Earlier studies conducted in Taiwan, India, Vietnam, Thailand, and Macau have applied CoRTN models to predict traffic noise in urban areas of which motorcycles occupied more than half of the total traffic volume ${ }^{(13,35,37)}$. These studies report the good performance of the CoRTN models since the differences between the measured and predicted noise level of $<3 \mathrm{dBA}^{(37)}$. However, our current study used a smaller number of sites compared with those earlier studies that have used a larger number of monitoring sites and the measurement was conducted during one day-time only. On the other hand, the measured noise levels may vary over time, particularly between the weekends and weekdays. More measurement locations and times can improve the assessment of exposure to traffic noise levels using the CoRTN model. This is because errors may decrease when longer measurement periods such as 18-h averaging measurement periods (e.g. between 06:00 and 24:00) are of used ${ }^{(38)}$.

Figure 4 shows the map of the predicted noise levels exposures in both schools. It is notable from the figure that high levels of noise are evident along the roadside, front of the schools, and the schoolyard. The map also shows that the classrooms were located in yellow, green, and blue zones, indicating both students and teachers were exposed to noise levels exceeding the maximum permitted noise level for schools (55 dBA). 


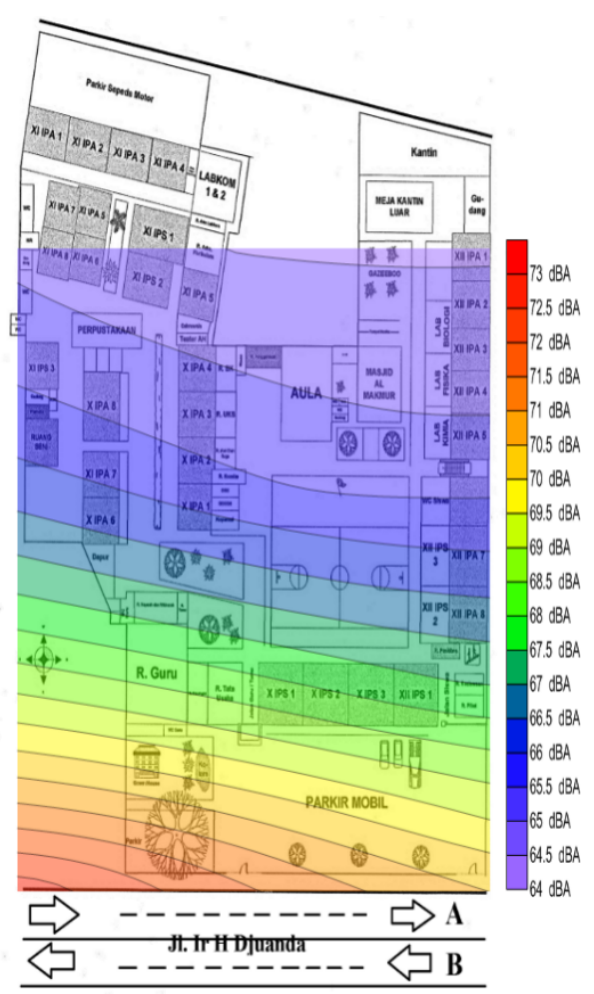

(a)

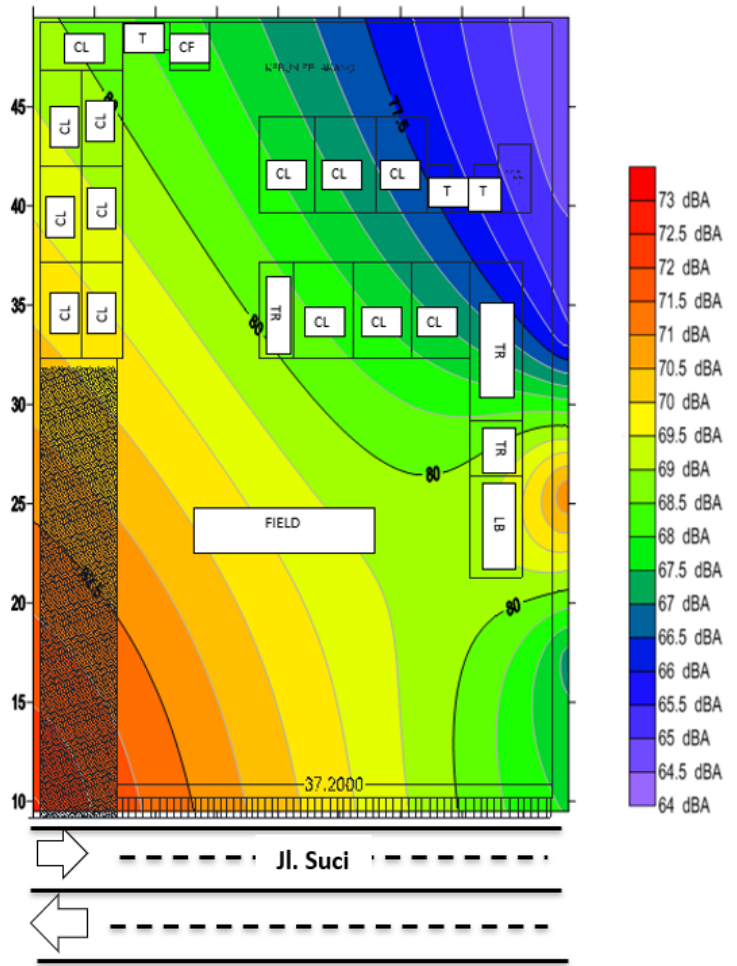

(b)

Figure 4. Noise maps of predicted CORTN noise levels at (a) Suci and (b) Djuanda road segments.

\subsection{Perception of traffic-related noise and its effects}

The responses given by the respondents (students and teachers) to the questionnaire identified their opinions regarding exposure to traffic noise at school and its effects. The results can be useful to find appropriate strategies. Table 5 shows the results collected from the questionnaires. There were $58.6 \%$ of the total respondents have known the definition of noise. Around $17.2 \%$ agreed that the schools have noise problems in the classroom, $18.2 \%$ in the school yard, and $39.8 \%$ in the roadside due to the traffic-related noise from the nearby main road. While $51.5 \%$ of the respondents know about the
Indonesia's noise acts and regulations, less than $50 \%$ of the respondents agree that noise problem must be controlled and know the effect of noise pollution on health. These results indicate that the awareness of public on the effects of noise and their interest in controlling the traffic-related noise still need to be developed. The negative impacts because of the noise exposures in both schools identified from the questionnaires were disturbance during studying-teaching (21.2\%), reducing the ability to focus $(15.2 \%)$, health effects include headache and hearing problem $(12.4 \%)$, communication trouble $(16.2 \%)$, and mental stress which accounted for $12.1 \%$ of the total respondents.

Table 5. Results of questionnaires on perception and knowledge about traffic noise and its effects

\begin{tabular}{llc}
\hline & \multicolumn{1}{c}{ Questions } & Agree (\%) \\
\hline 1 & Knowledge about the definition of noise & 58.6 \\
2 & Noise problem inside the classroom due to traffic-related activities & 17.2 \\
3 & Noise problem in front of the class room due to traffic-related activities & 18.2 \\
4 & Noise problem in the outdoor due to traffic-related activities & 39.8 \\
5 & Knowledge and awarenessof anyacts/regulations concerning noise pollution. & 51.5 \\
6 & Knowledge of the effect of noise pollution on health & 43.4 \\
7 & Noise problem must be controlled & 35.5 \\
\hline & B. Effect of noise & 21.2 \\
\hline 1 & Disturbance during studying/teaching & 15.2 \\
2 & Affecting the ability to focus & 16.2 \\
3 & Trouble communicating & 12.4 \\
4 & Headache / hearing disturbance & 12.1 \\
5 & Emotional balance disturbance (mental stress) & \\
\hline
\end{tabular}




\subsection{Future mitigation and adaptation strategies for traffic-related noise}

The results of both measurements and predictions show that noise problems due to traffic-related sources exist in both schools' areas since the noise levels were in a critical range. Therefore, it is important to develop measures to reduce the noise pollution from the main road. The recommendation of the measures was proposed by considering data gained from the results of noise measurements and CoRTN predictions as well as questionnaires which were administered to the school's students and teachers. Accordingly, the recommendation of noise mitigation measures was focused on the noise sources (traffic activities) and pathways as follow: (1) traffic flow limitation and vehicle speed reduction; (2) noise barriers implementation; and (3) noise insulation of school building facade.

(1) Traffic flow limitation and vehicles speed reduction

Traffic noise mitigation measure has the potential to affect a significant reduction in exposure at roadsides ${ }^{(39)}$. Previous studies demonstrate that substantial reductions in the exposure to traffic-related noise can be achieved through the limitation of traffic flows and associated traffic speeds in the study area $^{(37)}$. The potential reduction can be achieved by limiting traffic range between 2 and $5 \mathrm{dBA}^{(38)}$. If traffic flow limitation is carried out through the limitation of heavy vehicles passing the roads by up to $10 \%$, then the noise level can be reduced by $3.5 \mathrm{dBA}^{(39)}$. In general, the reductions of noise achieved by implementing speed reductions are less than those by traffic flow reduction ${ }^{(39)}$. Nonetheless, maintaining vehicles speed within the range of 30 to $60 \mathrm{~km} /$ hour could reduce the noise level up to $5 \mathrm{dBA}^{(40)}$. Each of these proposed strategies or combinations of traffic flow limitation and vehicles speed reduction strategies do not require high costs but effective enough for reducing traffic-related noise and the changes on the space and built environment are minimal. However, legal permits and coordination with the relevant government/local agencies are important to limit human exposure to road traffic noise in urban areas. Moreover, considering the schools are located on primary roads, law enforcement should be involved to ensure the successful of this measure plan.

(2) Noise barriers implementation

The use of noise barriers could be used strategically in urban areas at roadside ${ }^{(39)}$. The proposed strategies include the use of vegetations and construction of barriers, which could reduced the noise levels by 1-5 dBA by selecting adequate appropriate trees and bushes. The selected vegetations could be planted in the front of the roadside schools at Suci and Djuanda road segments as Murphy \& King (2011) suggested through vegetation barrier erected 2 and $3 \mathrm{~m}$ along the roadways ${ }^{(39)}$. Constructing low barriers along both schools could also reduce the noise levels by $3 \mathrm{dBA}$. Further noise reduction could be obtained by applying an absorbing surface to the existing barrier ${ }^{(39)}$. Noise barriers implemented for mitigation, however, relatively result in localized impact, costly, requires land, and may reduce the aesthetics of the environment $^{(41)}$. However, it is important to obtain financial supports for implementing this measure thus not be a burden for children studying at these schools.

(3) Noise insulation on school building façade Insulation on the facade of the school building can be carried out by replacing existing windows with double or triple glazed windows. This method can reduce noise levels from 15 to $25 \mathrm{dBA}$, and it is expected indoor noise level can be maintained between 38 and $44 \mathrm{dBA}^{(42)}$. The method is appropriate to be applied in high density areas such as city centers, as well as school and office buildings ${ }^{(42)}$. Yet changes in the environmental aesthetic as well as high cost for development and maintenance are the main challenges. External funding is needed to support the implementation of this noise mitigation strategy.

\section{CONCLUSIONS}

Traffic was the main source of noise within the roadside school's environment located in Djuanda and Suci road segments. The roadside noise levels of the primary road were above the permissible level set by $\mathrm{WHO}$ and the Ministry of Environment (65 dBA). The measured and CoRTN model predicted traffic-related noise levels in the front of the school and schoolyard have exceeded the recommended outdoor noise level limit of $55 \mathrm{~dB}$ for educational institution environment. The CoRTN can be applied for predicting the noise in urban settings such as Bandung where motorcycles posed of at least one-third of the total vehicle fleet. However, further study is necessary to generate more reliable predicted traffic noise levels through the most recent traffic data, and more reliable trafficnoise measurements. The mitigation and adaptation measures for mitigating traffic noise levels at the source and pathways that can be applied include limiting traffic flow and vehicle speed, implementing of noise barriers, and 
insulating noise at the building façade. Yet, a further study assessing the feasibility of these proposed measures would of beneficial.

\section{ACKNOWLEDGEMENT}

This study was supported by Environmental Engineering Study Program, Institut Teknologi Nasional Bandung. We are thankful to Wawan Wirawan for his assistance, particularly in revising figures in the manuscript.

\section{REFERENCES}

1. Prüss-Ustün, A.,Wolf, J., Corvalán, C., Neville, T., Bos, R., \& Neira, M. (2017). Diseases due to unhealthy environments: an updated estimate of the global burden of disease attributable to environmental determinants of health. Journal of public health, 39(3), 464-475.

2. Van Kempen, E., Casas, M., Pershagen, G., \& Foraster, M. (2018). WHO environmental noise guidelines for the European region: a systematic review on environmental noise and cardiovascular and metabolic effects: a summary. International Journal of Environmental Research and Public Health, 15(2), 379.

3. World Health Organization. (2019, 10 September 2020). Environmental noise guidelines for the European region. Retrieved from https://www.euro.who.int/en/publications.

4. Le Prell, C.G. (2019). Effects of noise exposure on auditory brainstem response and speech-in-noise tasks: A review of the literature. International Journal of Audiology,. 58(sup1), p. S3-S32.

5. Peris, E. \& B. Fenech. (2020). Associations and effect modification between transportation noise, self-reported response to noise and the wider determinants of health: A narrative synthesis of the literature. Science of The Total Environment: 15(748), 141040

6. Van Kamp, I. \& H. Davies. (2013). Noise and health in vulnerable groups: a review. Noise and health, 15(64), 153.

7. Schubert, M., Hegewald, J., Freiberg, A., Starke, K. R., Augustin, F., Riedel-Heller, S. G., ... \& Seidler, A. (2019). Behavioral and emotional disorders and transportation noise among children and adolescents: a systematic review and meta-analysis. International Journal of Environmental Research and Public Health. 16(18), 3336.

8. Radam, I.F. \& E. Heriyatna. (2018). A Correlation analysis of noise level and traffic flow: case of one-way road in Banjarmasin.
Asian Journal of Applied Sciences, 6(2), 6064.

9. Bhang, S. Y., Yoon, J., Sung, J., Yoo, C., Sim, C., Lee, C., ... \& Lee, J. (2018). Comparing attention and cognitive function in school children across noise conditions: a quasi-experimental study. Psychiatry Investigation. 15(6), 620.

10. Clark, C. \& K. Paunovic. (2018). WHO Environmental noise guidelines for the European Region: A systematic review on environmental noise and cognition. International journal of Environmental Research and Public Health. 15(2), 285.

11. Fecht, D., Hansell, A. L., Morley, D., Dajnak, D., Vienneau, D., Beevers, S., ... \& Gulliver, J. (2016). Spatial and temporal associations of road traffic noise and air pollution in London: Implications for epidemiological studies. Environment International. 88, 235242.

12. Alam, P., Ahmad, K., Afsar, S. S., \& Akhtar, N. (2020). Noise monitoring, mapping, and modelling studies - a review. Journal of Ecological Engineering. 21(4), 83-94.

13. Sheng, N., Z. Xu, and M. Li. (2015). The performance of CRTN model in a motorcycle city. Mathematical Problems in Engineering. 2015.

14. Sanjaya, H., Supriyani, P., \& Sufanir, A. M. S. (2018). Perhitungan kebisingan pada rumah sakit dan sekolah akibat arus lalu lintas di Jalan LLRE Martadinata Kota Bandung (Hal. 133-143). Reka Racana: Jurnal Teknil Sipil. 4(1), 133.

15. Badan Pusat Statistika. (2020, 2 Desember 2020). Jawa Barat dalam angka tahun 2020. Retrieved from https://jabar.bps.go.id/

16. Decree of the Minister of Public Works and Public Housing No. 245 of 2015 about the determination of primary roads according to their functions as arterial and collector roads. Ministry of Public Works and Public Housing: Directorate of Bina Marga.

17. Departemen Pemukiman dan Prasarana Wilayah. (2004, 4 Maret 2019). Survey pencacahan lalu lintas dengan cara Manual (Pd T-19-2004-B). Retrieved from http://sni.litbang.pu.go.id/

18. Department of Transport. (1988). Calculation of road traffic noise (CRTN). London: Department of Transport, Welsh Office, HMSO.

19. de Lisle, S. (2016). Comparison of road traffic noise prediction models: CoRTN, TNM, NMPB, ASJ RTN. Acoustics Australia. 44(3), 409-413. 
20. Lakawa, I., Samang, L., Selintung, M., \& Hustim, M. (2016). Noise level study based on traffic characteristics, physical, and environmental aspects of road. International Journal of Civil Engineering and Technology (IJCIET). 7(1), 188-198.

21. Wen, X., Lu, G., Lv, K., Jin, M., Shi, X., Lu, F., \& Zhao, D. (2019). Impacts of traffic noise on roadside secondary schools in a prototype large Chinese city. Applied Acoustics, 2019. 151, 153-163.

22. Adeke, P., A. Atoo, \& E. Zava. (2018). Modelling traffic noise level on roadside traders at Wurukum market area in Makurdi town, Benue state-Nigeria. Nigerian Journal of Technology. 37(1), 28-34.

23. Nassiri, P., Karimi, E., Monazzam, M. R., Abbaspour, M., \& Taghavi, L. (2016). Analytical comparison of traffic noise indices-A case study in District 14 of Tehran City. Journal of Low Frequency Noise, Vibration and Active Control. 35(3), 221-229.

24. Swain, B.K. \& Goswami S. (2014). Analysis and appraisal of urban road traffic noise of the City of Cuttack, India. Pakistan Journal of Scientific \& Industrial Research Series A: Physical Sciences, 57(1), 10-19.

25. Litvinova, N. (2019). Research of levels of noise generated by road traffic in urban areas. IOP Conference Series: Earth and Environmental Science. IOP Publishing. 272, 022126.

26. Agent, K.R. \& R.C. Deen. (1972). Noise pollution and abatement: a review of literature. Kentucky Transportation Center Research Report. 923.

27. Grubesa, S. \& M. Suhanek. (2020, 9 May 2020). Traffic Noise. Noise Pollution. IntechOpen. Retrieved from https://www.intechopen.com/books/noiseand-environment/traffic-noise.

28. Peng, J., J. Parnell, \& N. Kessissoglou. (2019). A six-category heavy vehicle noise emission model in free-flowing condition. Applied Acoustics. 143, 211-221.

29. Malec, A. \& G. Borowski. (2018). Monitoring of road noise in the urban environment of Lublin. Journal of Ecological Engineering, 19(4).

30. Halim, H., Abdullah, R., Nor, M. J. M., Aziz, H. A., \& Rahman, N. (2017). Assessment of road traffic noise indices in urban residential areas of Klang Valley, Malaysia. AIP Conference Proceedings. 1892(1), 040002.

31. Kumar, R., A. Mukherjee, \& V. Singh. (2017). Traffic noise mapping of Indian roads through smartphone user community participation. Environmental Monitoring and Assessment. 189(1), 17.

32. Mansourkhaki, A., M. Haghiri, \& M. Berangi. (2018). A modified noise-prediction model for highways with significant motorcycle traffic. Proceedings of the Institution of Civil Engineers-Transport.

33. Cebon, D., (1993). Interaction between heavy vehicles and roads. SAE Technical Paper. SP-951.

34. To, W. M., Ip, R. C., Lam, G. C., \& Yau, C. T. (2002). A multiple regression model for urban traffic noise in Hong Kong. The Journal of the Acoustical Society of America. 112(2), 551-556.

35. Mak, C., W. Leung, \& G. Jiang. (2010). Measurement and prediction of road traffic noise at different building floor levels in Hong Kong. Building services engineering research and technology, 31(2), 131-139.

36. Patthanaissaranukool, W., K. Bunnakrid, \& T. Sihabut. (2019). Applying mathematical modeling to predict road traffic noise in Phuket Province, Thailand. Int J Geomate. 17, 133-139.

37. Rajakumara, H. \& R.M. Gowda, (2008). Road traffic noise prediction models: a review. International Journal of Sustainable Development and Planning. 3(3), 257-271.

38. Gulliver, J., Morley, D., Vienneau, D., Fabbri, F., Bell, M., Goodman, P., ... \& Fecht, D. (2015). Development of an open-source road traffic noise model for exposure assessment. Environmental Modelling \& Software. 74, 183-193.

39. Murphy, E., \& King, E. A. (2011). Scenario analysis and noise action planning: Modelling the impact of mitigation measures on population exposure. Applied Acoustics, 72(8), 487-494.

40. Desarnaulds, V., Monay, G., \& Carvalho, A. (2004). Noise reduction by urban traffic management. Proceedings ICA 2004. IV, 3257-3260.

41. Scholes, W. E., Salvidge, A. C., \& Sargent, J. W. (1971). Field performance of a noise barrier. Journal of Sound and Vibration, 16(4), 627-642.

42. Secchi, S., Astolfi, A., Calosso, G., Casini, D., Cellai, G., Scamoni, F., ... Shtrepi, L. (2017). Effect of outdoor noise and façade sound insulation on indoor acoustic environment of Italian schools. Applied Acoustics, 126, 120-130. doi:10.1016/j.apacoust.2017.05.023. 